Joanna Kotowska

\title{
DWA ŻYWIOŁY BEZKRESU. WODA I POWIETRZE W FILOZOFII GASTONA BACHELARDA
}

Nie wnika się $w$ nieskończoność uciekając ku innej nieskończoności.

Umberto Eco

\section{TEORIE I APORIE}

Słowa Umberto Eco, obrane za motto artykułu, zostały zaczerpnięte z powieści Wahadło Foucaulta. Potraktowane zostaną jednak nieco przewrotnie, ponieważ niniejszy tekst jest spojrzeniem na kwestię nieskończoności z perspektywy innej - albo raczej innych - nieskończoności. Jak inaczej bowiem ujrzeć abstrakcyjny, wymykający się definicjom bezkres, jeśli nie w jego bardziej przystępnym, skonkretyzowanym odbiciu? Owym materialnym echem są żywioły, to jest substancje, z których przynajmniej dwie można uznać za pewną figurę, przybliżającą ideę bezkresu. Taki też jest cel pracy: pokazanie związku między pojęciem nieskończoności a jego realizacjami na planie fizycznym, to jest wodą i powietrzem, widzianymi przez pryzmat współczesnej 
teorii elementarnej francuskiego filozofa Gastona Bachelarda, autora badań nad marzeniami i obrazami poetyckimi, a także twórcy krytyki tematycznej zainspirowanej psychoanalizą. Żywioł rozumiany będzie więc na dwa sposoby: jako swoisty rodzaj nieskończoności, posiadający właściwości, cechy i specyficzne wyróżniki, pozwalające mu zaistnieć w przestrzeni, a także jako przyczynek do rozważań o nieskończoności w ogóle. Należałoby jednak rozpocząć od odrobiny historii, co pozwoli uporządkować charakter i sposób pojmowania obu terminów na przestrzeni wieków, a także zwróci uwagę na istotny aspekt ich wzajemnego powiązania.

Cztery potężne, niezmierzone i tajemnicze siły przyrody od wieków fascynowały największe umysły epoki i inspirowały do tworzenia wielorakich koncepcji, zarówno naukowych jak i literackich. W europejskiej tradycji filozoficznej, wyrosłej na gruncie greckiej kultury antycznej, próby „ujarzmienia” czyli uteoretyzowania żywiołów sięgają czasów jońskich filozofów przyrody (ok. V-III wiek p.n.e.). I tak Tales z Miletu podstawową zasadę wszechrzeczy utożsamił z wodą, dla Anaksymenesa z Miletu arché stanowiło powietrze, z kolei Ksenofanes z Kolofonu uznał za pierwotną substancję ziemię, a Heraklit ogień. I wreszcie Anaksymander z Miletu jako pierwszy strukturę świata oparł na współistnieniu wszystkich czterech elementów. Teorię tą pogłębił i rozbudował Empedokles z Akragas, dzięki czemu to właśnie on zasłużył w oczach badaczy takich jak Krystyna Wilkoszewska ${ }^{1}$ na miano „ojca filozofii żywiołów”. Myśl Jończyków zainspirowała najpierw Platona i Arystotelesa² a później także wielu innych myślicieli,

${ }^{1}$ Zob. K. Wilkoszewska (red.), Estetyka czterech żywiołów: ziemia, woda, ogień, powietrze, Universitas, Kraków 2002, s. 264.

${ }^{2}$ Co ciekawe, Arystoteles uznał koncepcję filozofów przyrody za niewystarczającą i wzbogacił ją o piąty element: eter, czyli kwintesencję substancji. Wieloelementowe spojrzenie na kwestię żywiołów - tak powszechne w kulturach 
uczonych, lekarzy, alchemików i psychoanalityków, którzy na przestrzeni wieków odwoływali się do hellenistycznych teorii elementarnych, zmieniając je, rozbudowując czy też z nimi polemizując. Jednak zadania na miarę Empedoklesa podjął się dopiero Gaston Bachelard, tworząc w latach czterdziestych i pięćdziesiątych XX wieku zbiór esejów o wodzie, ogniu, powietrzu i ziemi ${ }^{3}$.

Analogicznie do wizji żywiołów, równie długą drogę przemierzała w filozofii idea nieskończoności. Zainteresowanie nieskończonością zrodziło się bowiem niemal równocześnie z formowaniem się poglądów na temat elementów - to jest wśród filozofów przyrody. Pierwsze wzmianki pojawiają się już w V wieku p.n.e. u Anaksymandra w jego koncepcji ápeironu, który oznaczał nie mającą kresu pramaterię, utożsamioną później przez jego ucznia, Anaksymenesa, z żywiołem powietrza. Próby zmierzenia się z nieskończonością owocowały powstawaniem wielu mniej lub bardziej skomplikowanych myśli i założeń, nierzadko wiodących wprost do aporii, takich jak paradoks Zenona z Elei („Achilles i żółw"), paradoks Proklosa, paradoks Galileusza czy paradoks Davida Hilberta („Hotel Hilberta”). W starożytności inne interesujące teorie tworzyli Eudokos z Knidos (pojęcie nieskończoności potencjalnej) czy Arystoteles (rozróżnienie nieskończoności potencjalnej i aktualnej oraz nieskończoności podziałów i krańców), rozwinięte w czasach nowożytnych przez Blaise'a Pascala

Środkowego i Dalekiego Wschodu (zob. S. Zięba, [w:] U. Mazurczak, M. Żak, Obraz $i$ żywioły. Materiały z Konferencji „Obraz i żywioły”, KUL, 11-12 października 2006, KUL, Lublin 2008, s. 13) - nieobce było również europejskim średniowiecznym i renesansowym badaczom: wspomnijmy chociażby o niezwykle barwnej postaci lekarza, alchemika i okultysty Paracelsusa, który w swoich traktatach alchemicznych tradycyjną grecką koncepcję żywiołów uzupełnił o trzy pierwiastki - tria prima czyli rtęć, siarkę i sól.

${ }^{3}$ Zob. K. Wilkoszewska, Estetyka..., s. 269. 
(indukcja matematyczna jako wykorzystanie nieskończoności potencjalnej). Warto wymienić także, między innymi, żyjącego w XIX wieku Georga Cantora, twórcę teorii mnogości oraz twierdzenia o istnieniu różnych typów nieskończoności, a współcześnie Benoîta Mandelbrota, autora geometrii fraktalnej, będącej swoistą ilustracją matematycznej powtarzalności ad infinitum. Złożoność, a nierzadko sprzeczność różnych koncepcji, badacz filozofii Paweł Polak tłumaczy w następujący sposób: bezkres „wykracza poza granice naszego codziennego doświadczenia. Zawodzą więc często nasze potoczne intuicje i pojawiają się paradoksy" . Przeczucie transcendowania codzienności stało się więc źródłem twórczego niepokoju oraz filozoficzno-matematycznych dociekań ludzi każdej epoki.

\section{2. ŻYWIOŁ JAKO PRETEKST DO ROZWAŻAŃ O NIESKOŃCZONOŚCI}

Przez wieki niejako wspólnej ewolucji pojęć nieskończoności i żywiołów nieunikniony był ich wzajemny wpływ; w efekcie niektórym elementom zaczęto przypisywać wymiar bezkresności. Najczęściej określano w ten sposób wodę i powietrze, zapewne ze względu na ich naturę, intuicyjnie przez człowieka pojmowaną jako esencjonalną bezkształtność, rozległość, nieograniczoność, a także pewną fizyczną nieuchwytność właściwą ciałom niestałym. Do ich analizy przyjęto $w$ tej pracy, jak już zostało powiedziane we wstępie, punkt widzenia Gastona Bachelarda, dwudziestowiecznego filozofa i fenomenologa. $\mathrm{W}$ dobie dominującego ducha scjentystycznego, Bachelard podjął się bowiem ambitnego zadania polegającego na naukowym zbadaniu czterech elementów

${ }^{4}$ P. Polak, Rozwój pojęcia nieskończoności. Dialog pomiędzy filozofia a matematyka, „Semina Scientiarum” 2002, nr 1, s. 34. 
przyrody w całym ich wieloznaczeniowym, symboliczno-obrazowym wymiarze, czyli przywrócenia nauce żywiołów, które, jak twierdzi Wilkoszewska, ,ignorowane przez naukę w jej dotychczasowym kształcie - zawłaszczane były bez reszty przez «ducha poetyckiego»"

Owo zamierzenie zrealizowało się $\mathrm{w}$ postaci sześciu książek, stanowiących rozbudowane studium czterech elementów: La Psychanalyse du feu (Psychoanaliza ognia), La Flamme d'une chandelle (Płomień świecy), L'Eau et les rêves (Woda i marzenia), L'Air et les songes (Powietrze i marzenia), La Terre et les rêveries de la volonté (Ziemia, wola i marzenia) oraz La Terre et les rêveries du repos (Ziemia, spoczynek $i$ marzenia ${ }^{\circ}$ ). Według ich autora to właśnie woda i powietrze są najsilniej ze sobą związane w wyobraźni materialnej poprzez proces onirycznej przemiany - podobnej alchemicznej transmutacji - jednego elementu w drugi. W marzeniach zdarza się, że ryba, żywiołak ${ }^{7}$ wody, łatwo staje się latającą rybą, to znaczy zwierzęciem, które poprzez zdolność lotu przekracza granice przypisanego sobie środowiska i staje się nieomal elementalem powietrza. Ta zdolność do wzajemnej przemiany/wymiany żywiołaków

${ }^{5}$ K. Wilkoszewska, Estetyka..., s. 269.

${ }^{6}$ Tłumaczenie tytułów dzieł nieprzetłumaczonych jeszcze na język polski podaję za Chudakiem i Tatarkiewicz (G. Bachelard, Wyobraźnia poetycka. Wybór pism, przeł. H. Chudak, A. Tatarkiewicz, PIW, Warszawa 1975).

${ }^{7}$ Żywiołak (inaczej elemental) to magiczna istota, stanowiąca ucieleśnienie jednego z czterech żywiołów. W tradycji europejskiej najbardziej rozpowszechnionymi inkarnacjami są: dla elementu ognia - salamandra lub Feniks, dla wody - Nimfa bądź Ondyna, dla powietrza - Sylf albo Elf, a dla ziemi - Gnom. O żywiołakach po raz pierwszy pisał już Paracelsus w XVI wieku. Zob. pisma Paracelsusa ( $w$ j. ang.): The Hermetic and Alchemical Writings of Paracelsus, przeł. A. Waite, t. II; Hermetic Medicine and Hermetic Philosophy, Shambhala, Berkeley 1976, s. 193; oraz (w j. niem.) Liber de nymphis, sylphis, pygmaeis et salamandris et de caeteris spiritibus, [w:] Paracelsus, Sämtliche Werke, Oldenbourg, München 1933. 
symbolicznie łączy ze sobą oba elementy, spajając je nierozerwalnie z jeszcze innym, kluczowym dla nas pojęciem nieskończoności i jego symbolem - lemniskatą.

\section{NIESKOŃCZONOŚĆ W DÓŁ}

Dla Gastona Bachelarda żywioł płynny w samej już swej istocie jawi się jako wieczna i niewyczerpana materia samorodna, która stale odradza się z siebie. Ponieważ nie posiada własnej formy, może przyjąć każdy kształt, zależnie od zbiornika, w którym się znajdzie. Jeśliby jednak chcieć ująć wodę $\mathrm{w}$ jakąś symboliczną formę, nie byłby to tradycyjny, alchemiczny trójkąt czy platoński dwudziestościan foremny, ale raczej koło, oznaczające brak początku i końca, a także połączenie i cykliczność przeciwieństw w tym dwóch najważniejszych: życia i śmierci. Ale o koncepcji wody-matki i wody-kostuchy będzie mowa nieco dalej. Póki co, jeszcze parę słów o formach.

Osią filozofii wody Bachelarda jest postawienie znaku równości między wszelką substancją ciekłą a samym żywiołem: „Każdy płyn jest wodą, wszystko, co płynie jest z wody [...] Płynność jest elementarnym charakterem wody"s ${ }^{\prime}$, podkreśla wyraźnie filozof. Niezależnie więc od swojej postaci i właściwości, każda materia o aspekcie ciekłym (mleko, błoto, krew, śluz, benzyna etc.) lub potencjalnie ciekłym (topliwe ciała stałe9 , jak śnieg czy lód, żywica

${ }^{8}$ G. Bachelard, L'Eau et les rêves, Corti, Paris 2009, s. 110 (przekład własny).

${ }^{9}$ Można by się pokusić o dołączenie do tego zbioru metali ciągliwych i kowalnych, jednak z zastrzeżeniem ich szczególnego statusu: z racji swojego pochodzenia, należą one do żywiołu tellurycznego, jednak pod wpływem ognia ujawniają swój półpłynny charakter. Więcej o metalurgii w kontekście elementarnym przeczytać można w dziele Bachelarda La Terre et les rêveries de la volonté, głównie w rozdziałach: „Le Lyrisme dynamique du forgeron” oraz „Le 
drzew etc.), czy choćby poetyckiej jego sugestii (falujące włosy, poruszane wiatrem łany trawy, niebieskie oczy, kolor morski etc.) jest czystą emanacją żywiołu. Dzięki takiemu utożsamieniu woda istnieje w niemal nieograniczonej ilości postaci. Dodatkowo, jej nieskończony potencjał twórczy wyraża się w dwóch głównych własnościach, będących właściwie jedną i tą samą wartością, ale o przeciwnych kierunkach: woda jest uniwersalnym rozpuszczalnikiem i zarazem łącznikiem różnych materii, które upłynnia i rozluźnia, rozrzedza. Sama chemicznie obojętna, w wyniku zmieszania z innymi substancjami może albo przejmować (a nawet wzmagać) ich właściwości albo je neutralizować: na przykład płyn, w którym rozpuszczone są związki mineralne - odżywia. Tak pojmowany żywioł wody staje się matką, wieczną i powszechną matrycą (pro)kreacji oraz fundamentem życia wszystkich stworzeń; przenika również materię nieożywioną ziemi, którą jest gleba. Jednak pojęcie matczyności wody rozumiane jako jej ożywczy, życiodajny i reprodukcyjny charakter to tylko jeden biegun definicji. Na drugim biegunie leży śmierć.

„Woda jest [...] zaproszeniem do umierania"10 - konstatuje Bachelard, rozmyślając nad wierszem Edgara Allana Poe For Annie. Pomijając już dość oczywisty aspekt toksycznych mikstur i innych ciekłych trucizn, żywioł ten nawet w czystym pod względem chemicznym stanie ma moc odbierania życia. Chociaż sam bezkresny, bywa niekiedy kresem dla żywych stworzeń: w przypadku śmierci przez utopienie, staje się płynnym grobem. Bachelard podsumowuje to obrazowo, odwołując się do symboliki elementali: woda,

Métallisme et le minéralisme" (G. Bachelard, La Terre et les rêveries de la volonté, Corti, Paris 2004, odpowiednio s. 130-174 i 221-270).

${ }^{10} \mathrm{G}$. Bachelard, L'Eau..., s. 68 (przekład własny). 
jako ojczyzna nimf, jest także ojczyzną martwych nimf ${ }^{11}$. Śmierć nie wyklucza jednak nieśmiertelności. Można by się pokusić o stwierdzenie, iż woda bywa metaforycznym „środkiem transportu" w nieskończoność: umieranie pojmowane jako dysolucja, czyli całkowite rozpuszczenie się i zjednoczenie z żywiołem, byłoby więc niejako przekroczeniem samej idei śmierci, bo czyż wtopienie się w element, stanie się jego integralną częścią nie oznacza przejęcia wszystkich jego cech, włącznie z pewnym specyficznym, właściwym mu rodzajem nieśmiertelności?

Warto dodać, że według Bachelarda śmierć wodna jest najłagodniejszą, najbardziej matczyną ze wszystkich formą śmierci, jako że stanowi pewnego rodzaju powrót do początku istnienia, przywodząc na myśl pierwotne skojarzenia $\mathrm{z}$ wodami płodowymi albo ramionami matki, które niby fale kołyszą do snu. W Bachelardowskim „kompleksie Ofelii" ${ }^{12}$ woda jest kobiecym samobójstwem, spokojnym zanurzeniem w wiecznym śnie. W „kompleksie Charona"13 jest natomiast - jak to ujmuje Anna Kamińska - „tajemniczą i straszną żeglugą"14, podróżą w zaświaty wraz z nocnym, żałobnym nurtem Styksu. Po przekroczeniu niewidzialnej granicy życia martwe, bezużyteczne już ciało opada wolno na dno, w głębiny stanowiące dla francuskiego filozofa „nieskończoność w dół”. Nie tylko zresztą wodnym głębiom nadaje Bachelard cechy bezkresu.

11 Tamże, s. 96.

${ }^{12}$ Tamże, s. 95-108.

${ }^{13}$ Tamże, s. 85-95.

${ }^{14}$ A. Kamińska, Gaston Bachelard: Rzeczywistość wyobraźni, [w:] suplement do miesięcznika „Ulica Wszystkich Świętych” 2004, nr 2 (55), w internecie: http://www.innyswiat.most.org.pl/ulica/4-42AnnaKaminska.pdf, s. 60 (dostęp: 1 XII 2013). 


\section{NIESKOŃCZONOŚĆ W GÓRĘ}

Tuż przy powierzchni wody żywioł płynny przechodzi w terytorium współdzielone $\mathrm{z}$ drugim elementem bezkresu: powietrzem. Tam też zapełnia się zwierzętami „z pogranicza”: latającymi rybami i ptakami morskimi. A sama tafla wody - materialna granica oddzielająca oba żywioły - staje się zwierciadłem, w którym odbija się niebo. Spokojna powierzchnia morza, rzeki czy nawet kałuży nabiera cech lustrzanych, co pozwala Bachelardowi mówić o „narcyzmie kosmicznym”, kiedy cały (wszech)świat przegląda się w lustrze wody. Ono też staje się osią symetrii dla zadziwiającej przemiany: to, co odbija, stapia się z tym, co odbijane - morze staje się odwróconym niebem. Wyraźny dotąd podział na „dół” i „górę” rozmywa się; żywioł wodny ukazuje swoją niesamowitą chłonność oraz pojemność: nie zatracając płynnego charakteru, nieskończoność wody przyjmuje w siebie inną nieskończoność. Łatwość przemian jest zresztą dla tego elementu charakterystyczna, tak w wymiarze czysto fizycznym (parowanie, topnienie, kondensacja etc.), jak i symbolicznym (mieszanie, dysolucja, łączenie żywiołów między sobą oraz z innymi substancjami $\left.^{16}\right)$.

W podobną metaforykę wpisuje się koncepcja Bachelarda dotycząca latania: szybowanie w przestworzach, czyli naprzemienne wznoszenie się i opadanie, jest oniryczną transpozycją podróży po falach kosmicznego oceanu. Wywołuje w marzącym o nim radość i poczucie niczym nieskrępowanej możliwości przemieszczania się, której podniebny lot jest manifestacją. Powietrze, z racji swojej nieograniczoności, nadaje się więc doskona-

${ }^{15}$ G. Bachelard, L'Eau..., s. 35.

${ }^{16}$ Zob. tamże, rozdział: Les Eaux composées, s. 109-131. 
le do wy(ob)rażenia abstrakcyjnego pojęcia wolności; w L'Air et les songes autor zapytuje retorycznie: „Czyż trzeba podkreślać, że w królestwie wyobraźni epitetem najbliższym rzeczownikowi powietrze jest epitet wolny?" ${ }^{\prime 17}$. Latanie jest jednak nie tylko oniryczną podróżą na skrzydłach (lub bez ich pomocy), jest także - a może przede wszystkim - godzeniem w sobie „dialektyki przepaści i szczytów"18. Nierozerwalnie związany z lotem strach przed upadkiem niekoniecznie jednak oznacza wkroczenie na terytorium żywiołu ziemi - spadanie dla Bachelarda odbywa się co prawda na osi wertykalnej, zaksjologizowanej lecz zasadniczo pozbawionej wektorów, a co za tym idzie, możliwy jest także upadek $w$ górę, czyli nieskończone osuwanie się w „odwróconą przepaść" ${ }^{19}$ nieba.

Paradoksalna natura powietrza ujawnia się w eterycznym królestwie myśli na jeszcze dwa sposoby: z perspektywy wyobraźni materialnej jest ono w zasadzie „nicością”, ponieważ nie posiada (w stanie wyidealizowanym) żadnych wyraźnie zauważalnych substancjalnych właściwości - takich jak forma, konsystencja, waga czy smak - a zarazem znajduje się wszędzie i wypełnia każdą możliwą przestrzeń. Natomiast dla wyobraźni dynamicznej obraz żywiołu komplikuje się do granicy abstrakcyjności: w swoich rozważaniach nad poetyką Nietzschego, Bachelard opisuje powietrze jako nieskończoną substancję, którą jednak przemierzyć można w jednej chwili, za jednym zamachem, na podobieństwo pioruna albo orła, albo strzały ${ }^{20}$.

\footnotetext{
${ }^{17}$ G. Bachelard, L’Air et les songes, Corti, Paris 2009, s. 14 (przekład własny).

${ }^{18}$ Tamże, s. 78.

${ }^{19}$ Tamże, s. 137.

${ }^{20}$ Tamże, s. 175.
} 
Z charakterystyką powietrza nierozerwalnie związany jest także kolor niebieski. Być może potocznie jest to raczej kolor wody, ale francuski filozof bardziej skłonny jest przypisać wodzie brak swoistej barwy czy też transparentność, co zresztą wynika z jego poglądu na oczyszczające właściwości tego żywiołu. Wracając do powietrza, lazur nieba jest, jak powiada Bachelard, „tłem absolutnym”"1, „kolorem prymarnie powietrznym"22, a ponieważ barwi bezmierną, niewyobrażalną przestrzeń nieboskłonu, jest także kolorem nieskończonym. Z kolei to, co niewyobrażalne w czystej swojej postaci, zdaje się wyzwalać w człowieku potrzebę materializacji. I tak, jak nie sprawiłoby najmniejszego kłopotu ujrzenie oczyma wyobraźni ognia, wody czy ziemi, tak przedstawienie powietrza jest sprawą niezwykle delikatną - eteryczną, chciałoby się rzec. Każda bowiem próba nadania mu jakiejś określonej formy czy cechy stałaby w sprzeczności z samą istotą substancji, którą charakteryzuje niewidzialność, amorficzność, nieokreśloność. Według Bachelarda, nie jest to jednak niemożliwe - w sukurs przychodzi tutaj kolor, albo może raczej kolor na skraju dematerializacji: barwa zaniku (zob. dalej). Autor L'Air et les songes przestrzega jednak przed zbyt „twardym”, „,szorstkim” i „solidnym" wyobrażeniem niebieskiego nieba ${ }^{23}$, które łatwo zmienia je w kryształ czy szafir, czyli w ciało stałe, substancję należącą

\footnotetext{
${ }^{21}$ Tamże, s. 213.
}

${ }^{22}$ G. Bachelard, La Terre et les rêveries de la volonté, Corti, Paris 2004, s. 286. W języku polskim związek ten wydaje się jeszcze bliższy: z punktu widzenia tworzywa językowego „niebieski” oznacza zarówno kolor, jak i przymiotnik derywowany od rzeczownika „niebo” (jakkolwiek nie używany już w tym znaczeniu w mowie potocznej, ale zachowany np. w języku religijnym - zob. wyrażenia typu „Ojciec Niebieski”, „Królestwo niebieskie” obecne w teologii judaizmu i wielu wyznań chrześcijańskich).

${ }^{23}$ Zob. G. Bachelard, L'Air..., s. 210-211. 
do żywiołu ziemi. Dla filozofa prawdziwa materializacja jest niesłychanie subtelna: lazur nieba dopiero wtedy reprezentuje żywioł powietrza, kiedy przedstawiony jest jako blednący kolor, pewna tylko sugestia barwy, która - delikatna i ulotna jak tchnienie - nie przeczy naturze samego elementu.

Uniwersum powietrza, tak odległe i nieuchwytne jako wyobrażenie, jest jednak bardzo człowiekowi bliskie; jednym z podstawowych warunków istnienia jest przecież proces oddychania. Co prawda Bachelard w swojej analizie żywiołu świadomie pomija ten aspekt ${ }^{24}$, należy jednak nadmienić, iż organizmy żywe czerpią swoje istnienie $\mathrm{z}$ bezmiaru otaczającego je powietrza. Wdychanie czyli swoiste „podłączenie” do źródła wiecznego trwania, jakim jest ów element, jest gwarantem (prze)trwania; z chwilą bowiem, w której mechanizmy respiracji w organizmie ustają, ciało przechodzi ze stanu życia w stan śmierci, stając się częścią materii nieożywionej żywiołu ziemi - albo też, w przypadku utonięcia, częścią żywiołu wody. Cykl krążenia ożywionej materii w przyrodzie się domyka.

\section{W STRONĘ CZTERECH ŻYWIOŁÓW}

Analizując Bachelardowskie wyobrażenie powietrza i wody nie sposób oprzeć się wrażeniu, że ma się do czynienia z koncepcją rozdzieloną na dwie dopełniające się części. Tworzą ją, z jednej strony, półkula wodna i płynne metafory bezkresu, z drugiej zaś strony półkula nieboskłonu i powietrzny „kraj nieskończoności” ${ }^{25}$. Jak mieliśmy już wielokrotnie możliwość zauważyć, granica między nimi jest nieostra, żywioły przenikają się, a niekiedy nawet

\footnotetext{
${ }^{24}$ Tamże, s. 25.

${ }^{25}$ Tamże, s. 11.
} 
w siebie zmieniają - zachodzi wtedy swoista „przemiana fazowa” elementów.

Postawione już na samym początku L'Air et les songes pytanie pokazuje jednak, że nie tylko dwa, a wszystkie cztery żywioły posiadają wpisany w swoją naturę aspekt nieskończoności. Bachelard docieka bowiem: „Powiedz mi, jaka jest twoja nieskończoność, a poznam sens twojego świata; czy jest to bezmiar morza czy nieba, głębokiej ziemi czy paleniska?"26. I o ile filozof relatywnie dużo miejsca poświęca refleksjom na temat bezkresu wody i powietrza, tak raczej pomija on element telluryczny i ognisty. A przecież czymże innym jest Bachelardowskie „wezwanie stosu”, jeśli nie zaproszeniem do spotkania z nieskończonością osiąganą w śmierci? Czym jest kontemplacja horyzontu, jak nie marzeniem o braku krańców? Nawet wymieniany w La Terre et les rêveries de la volonté elemental chtoniczny, wąż, przywodzi na myśl mitycznego Uroborosa. Nieskończoność ziemi i ognia czeka na zbadanie.

${ }^{26}$ Tamże, s. 11 (przekład własny). 


\title{
TWO ELEMENTS OF ENDLESSNESS. WATER AND AIR IN GASTON BACHELARD'S PHILOSOPHY
}

\author{
SUMMARY
}

The article proposes to look at the idea of the infinity from the perspective of a French philosopher, Gaston Bachelard. His theory concerning the four elements is one of the twentieth century's most interesting elementary concepts. The aim of this work is to show a manifest link between the notion of the infinity and its realizations (materializations) on the physical plane, that is to say Bachelard's water and air. Both of these elements represent their own, specific kind of infinity, which is nonetheless very close to a man, because not only conceivable but also present in everyday life. Every single contact with the element is a touch of infinity.

KEYWORDS

air, elements, infinity, water, Bachelard G. 